\title{
Campylobacter spp. as a foodborne pathogen: a review
}

Joana Silva, Daniela Leite, Mariana Fernandes, Cristina Mena, Paul Anthony Gibbs and Paula Teixeira*

CBQF/Escola Superior de Biotecnologia, Universidade Católica Portuguesa, Porto, Portugal

Edited by:

Kostas Koutsoumanis, Aristotle

University, Greece

Reviewed by:

Sandra Torriani, Università degli Studi di Verona, Italy

Alexandra Lianou, Aristotle University

of Thessaloniki, Greece

*Correspondence:

Paula Teixeira, CBQF/Escola Superior

de Biotecnologia, Universidade

Católica Portuguesa, R. Dr. António

Bernardino de Almeida, 4200-072

Porto, Portugal

e-mail: pcteixeira@esb.ucp.pt
Campylobacter is well recognized as the leading cause of bacterial foodborne diarrheal disease worldwide. Symptoms can range from mild to serious infections of the children and the elderly and permanent neurological symptoms. The organism is a cytochrome oxidase positive, microaerophilic, curved Gram-negative rod exhibiting corkscrew motility and is carried in the intestine of many wild and domestic animals, particularly avian species including poultry. Intestinal colonization results in healthy animals as carriers. In contrast with the most recent published reviews that cover specific aspects of Campylobacter/campylobacteriosis, this broad review aims at elucidating and discussing the (i) genus Campylobacter, growth and survival characteristics; (ii) detection, isolation and confirmation of Campylobacter; (iii) campylobacteriosis and presence of virulence factors; and (iv) colonization of poultry and control strategies.

Keywords: Campylobacter spp., foodborne pathogens, virulence factors, antimicrobial susceptibility, control measures

\section{THE GENUS CAMPYLOBACTER}

It is believed that the first report concerning Campylobacter was back in 1886 by Theodore Escherich who observed and described non-culturable spiral-shaped bacteria (Vandamme, 2000; King and Adams, 2008; Vandamme et al., 2010). After this, Campylobacter was identified for the first time in 1906 when two British veterinarians reported the presence of "large numbers of a peculiar organism" in the uterine mucus of a pregnant sheep (Skirrow, 2006; Zilbauer et al., 2008). In 1913, McFadyean and Stockman isolated these microorganisms from aborted bovine fetuses. Later in 1927, Smith and Orcutt named a group of bacteria, isolated from the feces of cattle with diarrhea, as Vibrio jejuni. Seventeen years later, in 1944, Doyle isolated a different vibrio from feces of pigs with diarrhea and classified them as Vibrio coli (Vandamme, 2000; Vandamme et al., 2010). Due to their low DNA base composition, their non-fermentative metabolism and their microaerophilic growth requirements, the genus Campylobacter was first proposed in 1963 by Sebald and Véron, distinguishing them from the "true" Vibrio spp. (On, 2001). After that, the study of Butzler et al. (1973) raised the interest in Campylobacter by noting their high incidence in human diarrhea (On, 2001). Since its inception, the taxonomic structure of the genus Campylobacter has experienced extensive changes and even some parts of the current genus taxonomy remain a matter of controversy and require further investigation (On, 2001; Debruyne et al., 2005). According to these latter authors, Debruyne et al. (2005), there are 14 validly described Campylobacter species. More recently, Fernández et al. (2008) stated that the genus comprises 20 species and subspecies. However, other authors have stated that there are 16 species with a further six subspecies within the genus Campylobacter (On, 2001; Foster et al., 2004).

Campylobacters have been known to be the cause of diseases in animals since 1909, but they have been generally recognized as a cause of human disease, only since about 1980.

The family Campylobacteraceae consists of two genera, Campylobacter and Arcobacter and occur primarily as commensals in humans and domestic animals (Vandamme, 2000). The genus Campylobacter contains small $(0.2-0.8 \mu \mathrm{m} \times 0.5-5 \mu \mathrm{m})$ Gramnegative, slender spirally curved rods. When two or more bacterial cells are grouped together, they form an "S" or a "V" shape of gullwing. The majority of the species have a corkscrew-like motion by means of a single polar unsheathed flagellum at one or both ends of the cell. The only exceptions are Campylobacter gracilis which is non-motile and Campylobacter showae which has multiple flagella (see Debruyne et al., 2005 for a comprehensive description of the taxonomy of Campylobacteraceae). Oxidase activity is present in all species except for C. gracilis. They neither ferment nor oxidize carbohydrates; instead they obtain energy from amino acids, or tricarboxylic acid cycle intermediates (Vandamme, 2000). Campylobacter jejuni hydrolyzes hippurate, indoxyl acetate and reduces nitrate. Most strains are resistant to cephalothin, and also resistance to fluoroquinolones, a category of antibiotics normally used to treat animal and human illness, has been reported (Koenraad et al., 1995).

Under unfavorable growth conditions, these microorganisms have the ability to form viable but non-culturable cells (VBNC; Portner et al., 2007). Cappelier (1997), observed under laboratory conditions, that Campylobacter strains, isolated from the soil around the broiler house, may have been transformed into viable but non-cultivable forms and might have become cultivable after passing through the intestinal tract of chickens. Many questions have been raised on whether non-culturability equates to non-viability (McKay, 1992), whether it is possible to convert the VBNC form to a culturable form (Jones et al., 1991; Beumer et al., 1992; Stern et al., 1994), and whether, indeed, a VBNC form of Campylobacter actually exists (ACMSF, 2004).

\section{GROWTH AND SURVIVAL CHARACTERISTICS}

Thermophilic Campylobacter species are able to grow between 37 and $42^{\circ} \mathrm{C}$, but incapable of growth below $30^{\circ} \mathrm{C}$ (absence of cold shock protein genes which play a role in low-temperature adaptation), with an optimum temperature of $41.5^{\circ} \mathrm{C}$. Levin 
(2007) suggested that these organisms should be referred to as "thermotolerant" since they do not exhibit true thermophily (growth at $55^{\circ} \mathrm{C}$ or above). However, a study by De Cesare et al. (2003) revealed that C. jejuni survived for more than $4 \mathrm{~h}$ at $27^{\circ} \mathrm{C}$ and $60-62 \%$ relative humidity on some common clean or soiled food contact surfaces. These characteristics, reduce the ability of campylobacters to multiply (i) outside of an animal host and (ii) in food during their processing and storage (Park, 2002). Growth does not occur in environments with water activity $\left(a_{\mathrm{W}}\right)$ lower than 0.987 (sensitive to concentrations of sodium chloride $(\mathrm{NaCl})$ greater than $2 \% \mathrm{w} / \mathrm{v}$ ), while optimal growth occurs at $a_{\mathrm{w}}=0.997$ (approximately $0.5 \% \mathrm{w} / \mathrm{v} \mathrm{NaCl}$ ).

Campylobacter spp. are easily inactivated by heat treatments with their $D$-value being less than $1 \mathrm{~min}$ (Table 1 ).

Freezing-thawing also reduces the population of Campylobacter spp. (Stern and Kazmi, 1989). In pure cultures, Campylobacter spp. are normally inactivated by frozen storage at $-15^{\circ} \mathrm{C}$ in as few as 3 days (Stern and Kotula, 1982); however, freezing does not eliminate the pathogen from contaminated foods (Lee et al., 1998). Hazeleger et al. (1995) revealed that aged C. jejuni cells survived the longest at $4^{\circ} \mathrm{C}$. Campylobacter spp. will not survive below a $\mathrm{pH}$ of 4.9 and above $\mathrm{pH} 9.0$ and grow optimally at $\mathrm{pH} 6.5-7.5$. These non-spore-forming and fastidious bacteria are essentially microaerophilic, growing best in an atmosphere with low oxygen tension $\left(5 \% \mathrm{O}_{2}, 10 \% \mathrm{CO}_{2}\right.$, and $85 \% \mathrm{~N}_{2}$; Garénaux et al., 2008).

\section{DETECTION, ISOLATION AND CONFIRMATION}

The sensitivity of Campylobacter spp. to oxygen and oxidizing radicals has led to the development of several selective media containing one or more oxygen scavengers, such as blood, ferrous iron,

Table 1 | Reported $D$-values for Campylobacter jejuni and $C$. coli under different conditions.

\begin{tabular}{|c|c|c|c|}
\hline $\begin{array}{l}\text { Temper- } \\
\text { ature }\left({ }^{\circ} \mathrm{C}\right)\end{array}$ & Media & $\begin{array}{l}D \text {-value } \\
\text { (min) }\end{array}$ & Reference \\
\hline 51 & $1 \%$ peptone* & 4.90 & $\begin{array}{l}\text { Blankenship and } \\
\text { Craven (1982) }\end{array}$ \\
\hline 51 & $\begin{array}{l}\text { Autoclaved ground } \\
\text { chicken breast meat* }\end{array}$ & 8.77 & \\
\hline 53 & $1 \%$ peptone* & 1.71 & \\
\hline 53 & $\begin{array}{l}\text { Autoclaved ground } \\
\text { chicken breast meat* }\end{array}$ & 4.85 & \\
\hline 57 & $1 \%$ peptone* & 0.25 & \\
\hline 57 & $\begin{array}{l}\text { Autoclaved ground } \\
\text { chicken breast meat* }\end{array}$ & 0.79 & \\
\hline 49.9 & $\begin{array}{l}\text { Phosphate-buffered } \\
\text { saline }{ }^{* *}\end{array}$ & 6.35 & $\begin{array}{l}\text { Moore and Madden } \\
\text { (2001) }\end{array}$ \\
\hline 55.4 & $\begin{array}{l}\text { Phosphate-buffered } \\
\text { saline }{ }^{* *}\end{array}$ & 1.48 & \\
\hline 55 & Heart infusion broth* & $5.3 \pm 0.4$ & Nguyen et al. (2006) \\
\hline 55 & Heart infusion broth** & $6.6 \pm 0.5$ & \\
\hline
\end{tabular}

*Campylobacter jejuni

${ }^{*}$ Campylobacter coli pyruvate, etc., and selective agents, particularly antibiotics. Most methods involve a pre-enrichment in a liquid medium, before plating on agar. The developments of methods for Campylobacter have been well-described by Corry et al. (1995).

In some protocols, in order to ameliorate the inhibitory effects of the selective agents on potentially damaged cells, initial suspension of samples is made into a basal broth without selective agents, with the latter being gradually added after a short period of incubation. In order to permit recovery of damaged cells, the incubation temperature may also be gradually increased from $37^{\circ} \mathrm{C}$ to the final incubation temperature of $41.5^{\circ} \mathrm{C}$. This methodology is the basis for one of the ISO standard methods (ISO, 1995, 2006a). However, for chicken samples, such a protocol was not necessary as maximal numbers were obtained by using a selective broth followed by plating on selective agars (Mason et al., 1999).

Several of the selective broths, e.g., Bolton broth (BB), Campylobacter enrichment broth (CEB), and Preston broth (PB), have been compared for their efficacy (Baylis et al., 2000). The incorporation of the enzyme Oxyrase in selective broths is particularly effective in reducing the levels of oxygen and improving the isolation of Campylobacter spp. from naturally contaminated samples (Abeyta et al., 1997). However, a blood free enrichment broth not requiring the addition of Oxyrase, nor special atmospheres has been tested and found to perform well against other more complex isolation methods (Tran, 1998).

Several selective agars have been formulated and tested for their efficacy in isolating campylobacters. For example, Preston, charchoal cefoperazone deoxycholate (CCDA) and Butzler agars have been found to be equally effective. The use of CCDA and incubation at $42^{\circ} \mathrm{C}$ rather than $37^{\circ} \mathrm{C}$ is usually the methodology of choice since it allows for the isolation of more Campylobacter strains (Zanetti et al., 1996).

Corry and Atabay (1997) developed CAT agar from modified CCDA by altering the levels of the antibiotics to permit growth of a wider range of strains of Campylobacter spp., notably Campylobacter upsaliensis. A later comparison by Federighi et al. (1999), of Karmali, Butzler, and Skirrow isolation agars after enrichment of a large number and wide range of samples in Preston or Park and Sanders broths, showed that Park and Sanders broth followed by isolation on Karmali agar was the more effective combination. The most recent standard method (ISO, 2006a) for detection and isolation, and a direct plating method for enumeration of campylobacters (ISO, 2006b), both use mCCDA as the selective agar. Bolton broth is used for the enrichment step and the suspension is incubated at $37^{\circ} \mathrm{C}$ in a microaerophilic atmosphere for $4-6 \mathrm{~h}$, followed by $41.5^{\circ} \mathrm{C}$ for $40-48 \mathrm{~h}$ and plating on mCCDA and another agar medium of the operator's own choice. However, methods for Campylobacter spp. are not commonly used in routine laboratories as the organisms are difficult to cultivate and to keep reference cultures.

Several alternative and rapid methods have been developed for detecting and confirming Campylobacter spp. e. g. those that include fluorescence in situ hybridization (FISH; Lehtola et al., 2006), latex agglutination (commercially available; e.g., Wilma et al., 1992; Microscreen ${ }^{\circledR}$ Campylobacter kit), and a physical enrichment method (filtration) that permits the separation of Campylobacter from other organisms present in the food matrix 
(Baggerman and Koster, 1992). Perhaps the most effective confirmation methods are those based on the polymerase chain reaction (PCR) reaction, since the phenotypic reactions are often atypical and difficult to read, e.g., the hippurate hydrolysis test for differentiating Campylobacter coli from C. jejuni. The PCR reaction has been combined with immuno-separation with some success (e.g., Docherty et al., 1996; Waller and Ogata, 2000) in detecting low numbers of the organism in only about $6 \mathrm{~h}$. However, some components of both food samples and selective broths can be inhibitory to the PCR reaction. More recently real-time PCR methods have been developed that show the potential of detecting as few as $1 \mathrm{cfu}$ in chicken samples, and in less than $2 \mathrm{~h}$ (Debretsion et al., 2007). Epidemiological studies (e.g., outbreak investigations) have been benefited from the use of molecular typing techniques such as PCR, random amplification of polymorphic DNA (RAPD) and pulsed field gel electrophoresis (PFGE).

\section{CAMPYLOBACTERIOSIS IN HUMANS: OCCURRENCE, SEVERITY AND COSTS}

Based on the Community Zoonoses Reports of the European Food Safety Authority (EFSA) and the European Centre for Disease Prevention and Control (ECDC) in their Community Zoonoses Reports, in the last 5 years, campylobacteriosis has been the most commonly reported zoonosis in the EU followed by salmonellosis and yersiniosis (EFSA, 2007, 2010c). In 2008, campylobacteriosis was the principal cause of zoonotic disease in humans with 190,566 reported confirmed cases (EFSA, 2010c). In 2007, more than 200,000 confirmed cases of human campylobacteriosis were reported by the 24 member states (MS), with an EU notification rate of 45.2 cases per 100,000 inhabitants. Rates varied depending on the MS. When compared to data for 2006, an increase of $14.2 \%$ was observed in the number of reported cases (EFSA, 2009). The food vehicle associated with the majority of the reported in 2007 campylobacteriosis infections was contaminated poultry meat. The Foodborne Diseases Active Surveillance Network (FoodNet) of the Centers for Disease Control and Prevention (CDC) in the USA estimates that in 2009, the number of reported infections and incidence per 100,000 population by Campylobacter was 6,033 and 13.02, respectively (Anonymous, 2010). In fact, more than 10,000 cases of campylobacteriosis are reported each year to the CDC (approximately six cases for each 100,000 persons in the population). However, many more cases remain undiagnosed or unreported (Anonymous, 2010). Estimates are that Campylobacter causes more than two million illnesses (or 1\% of the population), 13,000 hospitalizations, and over 100 deaths each year in the USA (Anonymous, 2007).

According to EFSA (2010a), clinical cases of campylobacteriosis is under-reported in the EU (27 MS): "there may be not less than 2 million and possibly as high as 20 million cases of clinical campylobacteriosis per year in the EU 27 MS."

In the EU, the reported foodborne outbreaks of campylobacteriosis are limited, constituting 2,1 , and $0.12 \%$ of the total reported campylobacteriosis cases in 2004/2005, 2006 and 2007, respectively (EFSA, 2006, 2007, 2009). In fact, most cases of human campylobacteriosis are sporadic. However, the Campylobacter Sentinel Surveillance Scheme Collaborators (2003) suggested that outbreaks of campylobacteriosis may be more common than previously suspected. In fact, the number of Campylobacter outbreaks reported in the United Kingdom (UK) in 2009 was similar to the sum of those reported for 2005-2008 (ACMSF, 2010). Table 2 reports examples of outbreaks that occurred worldwide in the recent years, mainly resulting from consumption of contaminated drinking water, raw milk, and chicken products. Further information on Campylobacter outbreaks in the USA can be found in the internet ${ }^{12}$ (accessed in October 2010). The outbreak investigations suggested that in over $25 \%$ of the cases, chicken was identified as the source of the outbreak; in $33 \%$ of the cases, the source was unknown (EFSA, 2010a). From 2010 until 2015, the UK Government increased the priority of "innovation strategy for Campylobacter." In the UK, Campylobacter is actually considered the most common cause of food poisoning, responsible for 321,000 estimated cases in England and Wales in 2008, with more than 15,000 hospitalizations and 76 deaths ${ }^{3}$.

Handling, preparation and consumption of broiler meat may account for $20-30 \%$ of human cases of campylobacteriosis, while $50-80 \%$ may be attributed to the chicken reservoir as a whole (EFSA, 2010a). According to EFSA (2010b), and with regard to the factors that may contribute to Campylobacter spread in live chickens and chicken carcasses, the above along with the fact that the levels of the pathogen found on single carcasses may also vary greatly, indicate that some slaughterhouses are more capable of controlling this organism than others. Other factors that

\footnotetext{
${ }^{1}$ http://www.pritzkerlaw.com/campylobacter-outbreaks/

${ }^{2}$ http://www.about-campylobacter.com/campylobacter_outbreaks

${ }^{3}$ http://www.food.gov.uk/multimedia/pdfs/campylobacterstrategy.pdf
}

Table 2 | Food products implicated in campylobacteriosis outbreaks occurring worldwide.

\begin{tabular}{lllll}
\hline Year & Location & Total no. of cases & Food implicated & Reference \\
\hline 2010 & Northumberland, UK & 24 & Chicken liver parfait & Inns et al. (2010) \\
2009 & Crete, Greece & 37 & Tap water & Karagiannis et al. (2010) \\
2008 & Washington, USA & 5 & Raw milk & Anonymous (2008) \\
2007 & British Columbia, Canada & 225 & Ingestion of mud during a mountain bike race & Stuart et al. (2010) \\
2007 & Røros, Norway & 105 & Untreated tap water & Jakopanec et al. (2008) \\
2005 & Madrid, Spain & 81 & Custard & Anonymous (2005) \\
2005 & Australian Capital Territory & 11 & Several chicken-containing dishes & Black et al. (2006) \\
2005 & Copenhagen, Denmark & 79 & Chicken salad & Mazick et al. (2006) \\
1984 & California, USA & 12 & Raw milk products & Anonymous (1984)
\end{tabular}


might also influence the risk of contamination with Campylobacter include the age of the slaughtered chickens, and the period of the year and the time of the day when carcasses are processed. On the other hand, depopulation of chicken flocks also increases the likelihood of infection since some of the chickens are retained from slaughter to continue growing. In fact, it is believed that during these practices, humans or other vectors may introduce Campylobacter and infect the remaining chickens (EFSA, 2010b).

Recently, EFSA described the factors influencing campylobacteriosis infections, namely the age (higher occurrence rates in children under 5 years old), the season (a higher number of campylobacteriosis cases is reported during the summer months), the strain variation (certain strains are less pathogenic than others), host immunity, travel and the demographic factors (i.e., the social economic status). Foodborne zoonoses are an important cause of morbidity and mortality worldwide; the World Health Organization (WHO) estimates that over two million people die each year from diarrheal diseases mainly caused by the ingestion of contaminated foods (WHO, 2005; EFSA, 2007).

European Food Safety Authority has emphasized the importance and recommended the establishment of an active surveillance of campylobacteriosis in all MS, including efforts to determine the uncertain and unreported campylobacteriosis cases. In addition, storage and genotyping of human and putative reservoirs of isolates in all MS have also been recommended.

Thereafter, it would be important to identify the Campylobacter properties of virulence, survival characteristics and ecology (EFSA, 2011).

The high numbers of Campylobacter cases are frequently associated with very large on-costs, i.e., medical expenses, lost wages, product recalls, legal costs, and other indirect expenses. Estimates are that each case of campylobacteriosis costs $\$ 920$ mainly due to medical and productivity expenses with an annual total cost of almost $\$ 1$ billion (CAST, 1994). As a result of campylobacteriosis, substantial worldwide losses are accumulated annually (Forsythe, 2000). Havelaar et al. (2005), estimated that in the Netherlands (with approximately 80,000 cases of gastroenteritis per year), the costs of illness caused by campylobacteriosis are about 21 million Euros per year.

\section{PATHOGENESIS OF CAMPYLOBACTER VIRULENCE FACTORS}

Specific virulence mechanisms have not yet been clearly elucidated for Campylobacter spp. probably due to the lack of pathogenesis similarity between campylobacters and other pathogens (Guerry, 2007; Dastia et al., 2010). Flagella-mediated motility, bacterial adherence to intestinal mucosa, invasive capability and the ability to produce toxins have been identified as virulence factors (van Vliet and Ketley, 2001; Asakura et al., 2007; Dastia et al., 2010). Despite the limited knowledge of the modus operandi of this pathogen, it is known that flagella are required for the colonization of the small intestine; after that it moves to the target organ, which is the colon (van Vliet and Ketley, 2001; Poly and Guerry, 2008). Invasion, which causes cellular inflammation, is probably resulting from the production of cytotoxins, and is followed by the reduction of the absorptive capacity of the intestine (Van Deun et al., 2007). It is thought that the ability of this pathogen to reach the intestinal tract is, in part, due to resistance to gastric acids and also to bile salts (Van Deun et al., 2007), even though the disease severity may depend on the virulence of the strain as well as on the host's immune condition (Zilbauer et al., 2008).

\section{FLAGELLA}

Motility, which increases under highly viscous conditions, is essential for colonization of the small intestine (Jagannathan and Penn, 2005; Guerry, 2007). Moreover, the role of flagella under different chemotactic conditions is essential for bacterial survival in the various ecological niches encountered in the gastrointestinal tract (Jagannathan and Penn, 2005).

The C. coli flagellum is composed of two highly homologous flagellins, FlaA which is the major one, and FlaB the minor one (Guerry, 2007). These are encoded by two flagellin genes arranged in tandem. The flaA gene is regulated by promoter $\sigma^{28}$ while flaB gene is regulated by the dependent promoter $\sigma^{54}$ (Jagannathan and Penn, 2005). The flaA gene seems to be essential for the invasion of epithelial cells, since it has been reported that a mutation in this gene leads to a truncated flagellar filament composed of fla $\mathrm{B}$ with a severe reduction in its motility (Guerry, 2007). However, a mutation in flaB appears to have no significance compared with a structurally normal flagellum (Guerry, 2007). The flaA gene is responsible for the expression of adherence, colonization of the gastrointestinal tract and invasion of the host cells (Jain et al., 2008), consequently arresting the immune response. In fact, it is believed that flagella possess another characteristic which is the ability to secrete non-flagellar proteins that may be associated with the virulence phenomenon itself (Poly and Guerry, 2008). C. jejuni possesses a polar flagellum that is composed of O-linked glycosylated flagellin; a two-component system comprised of the sensor FlgS and the response regulator FlgR is central for the regulation of the Campylobacter flagellum (Dastia et al., 2010).

\section{CYTOLETHAL DISTENDING TOXIN}

Cytolethal distending toxin (CDT) is widely distributed among Gram-negative bacteria (Ceelen et al., 2006; Ge et al., 2008) and is the best characterized of the toxins produced by Campylobacter spp. It has been described as an important virulence factor of this pathogen (Asakura et al., 2008). CDT holotoxin, composed of three subunits encoded by the $c d t \mathrm{~A}, c d t \mathrm{~B}$ and $c d t \mathrm{C}$ genes, causes eukaryotic cells to arrest in the G2/M phase of the cell cycle, preventing them from entering mitosis and consequently leading to cell death (Yamasaki et al., 2006; Ge et al., 2008; Zilbauer et al., 2008). In contrast to CdtB, the roles of CdtA and CdtC are still rather unclear and require further investigation (Ceelen et al., 2006), partly because these proteins tend to combine with the bacterial outer membrane which probably causes crosscontamination (Lara-Tejero and Galan, 2001). Despite this, CdtA and $\mathrm{CdtC}$ are thought to be essential for $\mathrm{CdtB}$ delivery into the host cell (Lara-Tejero and Galan, 2001), being responsible for binding the CDT holotoxin to the cell membrane (Lara-Tejero and Galan, 2001; Ge et al., 2008). After that, the CdtB active subunit, which has DNaseI-like activity, induces host DNA damage by breaking its double strand (Ge et al., 2008).

In fact, to be functionally active, all three $c d t$ gene products must be present (Lara-Tejero and Galan, 2001; Asakura et al., 
2008). Cdt genes have already been cloned and/or sequenced for C. jejuni (Pickett et al., 1996; Bang et al., 2001) and more recently for C. coli and Campylobacter fetus (Asakura et al., 2007, 2008). According to some authors, the $c d t$ gene clusters are ubiquitously distributed in C. jejuni, C. coli, and C. fetus in a species-specific manner (Eyigor et al., 1999; Bang et al., 2001; Asakura et al., 2007, 2008; Samosornsuk et al., 2007).

\section{ANTIMICROBIAL SUSCEPTIBILITY OF CAMPYLOBACTER}

Antibiotic resistance in Campylobacter is emerging globally and has already been described by several authors and recognized by the WHO, as a problem of public health importance (Greig, 2003; Takkinen et al., 2003; McDermott et al., 2005; Moore et al., 2006).

Most patients infected with Campylobacter spp. will recover without any specific treatment other than replacing lost fluids and electrolytes. Antibiotics, generally macrolides, tetracycline and (fluoro)quinolones, are reserved for more severe cases. However, the increasing resistance to (fluoro)quinolones, tetracycline and erythromycin of C. coli and C. jejuni strains, might compromise the efficacy of this treatment (Aarestrup and Engberg, 2001; Engberg et al., 2001; Gibreel and Taylor, 2006; Alfredson and Korolik, 2007). Gentamycin is the only alternative to fluoroquinolones and macrolides, for systemic infections caused by Campylobacter spp. (Aarestrup and Engberg, 2001).

Although comparable standardized procedures for susceptibility testing are available for a wide range of organisms, based on the guidelines defined by the National Committee for Clinical Laboratory Standards (NCCLS), no internationally accepted criteria are available for susceptibility testing of Campylobacter spp. Specifically, in the European Community there is still a lack of standardization among the monitoring programs available in each MS (EFSA, 2008). As a result, there is a debate in the literature regarding the interpretation of the results of antimicrobial resistance (Ge et al., 2003; Moore et al., 2006). Nevertheless, those studies comparing the evolution of antibiotic resistance patterns with time, observed rapid developments for both clinical (Endtz, 1991; Rautelin et al., 1991; Sánchez et al., 1994; Lucey et al., 2002; Gallay et al., 2007; Mazi et al., 2008) and food isolates (Endtz, 1991; Lucey et al., 2002; Gallay et al., 2007; Mazi et al., 2008) and an increase in multiple resistant strains in food production environments is recognized (Smole Možina et al., 2009).

Antibiotics have been indiscriminately used in animal production for decades in order to control, prevent and treat infections, and enhance animal growth (Rožynek et al., 2007; EFSA, 2008; Igimi et al., 2008). There is strong evidence that supports the hypothesis that the unregulated use of antimicrobial agents in food animal production has led to the emergence and spread of antibiotic resistance among Campylobacter spp. The approval and use of fluoroquinolones in poultry in Europe and the USA were followed by increases in fluoroquinolone resistance in Campylobacter spp. isolated from animals and human patients (Takkinen et al., 2003; Smith and Fratamico, 2010). A higher prevalence of (multi)resistant strains has been reported for animal and meat isolates than for human isolates (EFSA, 2009). In countries were use of antibiotics in broiler production is uncommon, the prevalence of resistant strains is very low (Norström et al., 2007). Campylobacter strains isolated from broiler chickens raised in conventional farms are significantly more resistant to antibiotics than those isolated from animals grown in organic regimes, since the use of antibiotics in the rearing of organic chickens is prohibited (Luangtongkum et al., 2006).

For reasons that remain unclear, $C$. coli strains isolated from poultry and other animals appear to harbor resistance to multiple antibiotics, such as macrolides and fluoroquinolones, more commonly than C. jejuni strains (D'lima et al., 2007; Kim et al., 2008).

Studies by Gallay et al. (2007) and Han et al. (2009) have demonstrated that the regulation policy of limiting the use of antimicrobial drugs in food animals has resulted in a reduction in the resistance to fluoroquinolones. However, other studies have suggested that resistance may persist for long time periods (Nelson et al., 2007; Price et al., 2007).

\section{PREVALENCE OF CAMPYLOBACTER SPP. IN FOODS AND SOURCES OF INFECTION}

Campylobacter spp. are commensal organisms routinely found in cattle, sheep, swine, and avian species. The avian species are the most common hosts for Campylobacter spp. probably because of their higher body temperature (Skirrow, 1977). Although all commercial poultry species can carry Campylobacter spp. the risk is greater from chicken because of the large quantities consumed (Humphrey et al., 2007).

\section{CAMPYLOBACTER SPP. IN CHICKENS}

Chicken meat comprises a substantial source of a high quality protein in most countries. Chicken meat is rich in essential amino acids along with vitamins and minerals. Lean chicken contains more protein than the same amount of lean roasted beef and the prices of chicken meat are lower than those of beef or pork. Additionally, chicken by-products are eaten widely due to their low price, special taste, and the short time required for preparation. The consumption of chicken and chicken products, however, has been implicated over the recent years in a large number of outbreaks of acute campylobacteriosis in human populations worldwide, in both industrialized and developing countries, and especially in children, the elderly and immuno-suppressed patients (Tauxe, 1992; Skirrow, 1998; Corry and Atabay, 2001). Most cases are associated with handling raw poultry, eating raw or undercooked poultry meat or cross-contamination of raw to cooked foods (Butzler and Oosterom, 1991; Tauxe et al., 1997; Corry and Atabay, 2001; Nadeau et al., 2002). El-Shibiny et al. (2005) suggested that the dominant species change to C. coli when the type of production system used is organic and free-range chickens. In a recent surveillance study in England and Wales, C. jejuni was reported to be responsible for more than 12 times the number of cases of human campylobacteriosis compared to C. coli (Friedman et al., 2000). However, C. coli is still known to be a significant cause of campylobacteriosis even if the risk factors associated with it may be different.

The intestinal tract of chicken, especially the cecum and colon, can harbor a large number of Campylobacter spp.; during processing, the intestinal tract may leak or rupture and the contents are transferred to the skin of the carcass (Berrang et al., 2001). Campylobacter spp. remain in a liquid film on the skin and 
become entrapped in its cervices and channels (Chantarapanont et al., 2003) which provides a favorable environment for crosscontamination (McMeekin et al., 1984). Persistence and survival of Campylobacter spp. are fostered by a suitable microenvironment of the skin (Chantarapanont et al., 2003) and even under frozen conditions or storage at $4^{\circ} \mathrm{C}$, Campylobacter spp. are able to persist in the carcass (Simmons and Gibbs, 1979). Previous studies reported that growth on skin stored at room temperature in a controlled atmosphere package is possible, increasing the risk for consumers if contaminated chicken is not adequately stored or handled (Lee et al., 1998; Scherer et al., 2006).

A study was carried out to investigate the effect of environmental temperatures over different seasons on the survival of C. jejuni in poultry. Wills and Murray (1997) demonstrated that Campylobacter spp. was a present concern in poultry especially during the warmer months (May through October). During these months 87-97\% of the samples tested were positive for C. jejuni. The lowest number of positive samples were obtained in December (7\%) and January (33\%). It was also reported that there was substantial variability in the intestinal colonization of C. jejuni across different broiler flocks at different ages in the production cycle.

\section{CAMPYLOBACTER SPP. IN OTHER FOODS}

Some published comparative information on the incidence of Campylobacter spp. in food animals confirms that these human pathogens are also commonly found in many types of food animals other than chicken, e.g., cattle, pigs, dairy cows, turkeys, duck, or lamb (Humphrey et al., 2007). In fact the digestive tract of healthy cattle has been demonstrated to be a significant reservoir for a number of Campylobacter species (Atabay and Corry, 1998), with prevalence of the enteropathogen in cattle ranging from $0-80 \%$.

The prevalence of Campylobacter spp. in sheep, about 20\%, is generally lower than in other animals (Zweifel and Stephan, 2004). The high prevalence of Campylobacter spp. in pigs has been reported in numerous studies and dressed pig carcasses have been shown to be more frequently contaminated than either beef or sheep (Nesbakken et al., 2003). This is most likely attributable to the fact that pig carcasses undergo a communal scalding stage early in the slaughter process combined with the fact that the skin remains on the carcass following all of the dressing procedures (Moore et al., 2005).

Contaminated shellfish have also been implicated as a vehicle in the dissemination of campylobacteriosis. Harvesting shellfish from Campylobacter-contaminated waters would appear to be the most likely cause of infection (Wilson and Moore, 1996).

Consumption of untreated water (Schorr et al., 1994) or rainwater (Eberhart-Phillips et al., 1997) has also been considered as a risk factor for campylobacteriosis. In an ecological study in Sweden, positive associations were found between the incidence of Campylobacter spp. and the average volume of water consumed per person. There were similar associations with ruminant density. These observations suggest that drinking water and contamination from livestock might also be important factors in explaining at least a proportion of human sporadic campylobacteriosis cases (Nygard et al., 2004).

Raw milk has also been identified as a vehicle of human gastroenteritis caused by Campylobacter spp. (Blaser et al., 1979;
Robinson et al., 1979; Porter and Reid, 1980; Potter et al., 1983). C. jejuni may be present in milk due to fecal cross-contamination during milking or as a result of udder infection (Doyle and Roman, 1982; Orr et al., 1995).

In addition to risks from food, especially poultry, and water consumption, contact with animals, either domestic pets or farm animals, presents another exposure pathway for human infection (Kapperud et al., 1992; Saeed et al., 1993; Schorr et al., 1994; Studahl and Andersson, 2000). Contamination of the environment by domestic and wild animal feces constitutes an additional risk for human infection via drinking (Duke et al., 1996; Frost et al., 2002; Said et al., 2003) or recreational water use (Adak et al., 1995) for example.

Most infections are believed to result from the ingestion of contaminated food, although the role of other, non-food exposures in the epidemiology of sporadic campylobacteriosis is still unknown (Brown et al., 2004). Point source outbreaks are thought to be relatively uncommon compared to those by other major enteric pathogens, although there is increasing evidence for localized transmission (Charlett et al., 2003). The primary source of contamination is believed to be animal feces. This is consistent with high carriage rates observed in poultry, pigs, and cattle (Kramer et al., 2000).

\section{COLONIZATION OF POULTRY AND TRANSMISSION ROUTES}

Flock positivity for Campylobacter spp. depends on the type of production system used. Positive flocks are generally more frequent among organic and free-range chickens than among intensively reared birds, probably due to increased environmental exposure (Hendrixson and DiRita, 2004). Consistent with exposure of the chickens to different environmental sources is the finding that organic and free-range chickens can be colonized with multiple genotypes of Campylobacter spp. (Newell and Wagenaar, 2000).

Reducing levels of Campylobacter spp. contamination associated with raw poultry requires considerable attention with regard to the application of good agricultural practices (GAP), as well as of good manufacturing practices (GMP) in poultry processing plants (Tauxe, 1992; Allos, 2001).

Before control can be properly applied it is important to identify the sources and routes of infection in housed flocks. Although it is generally agreed that the presence of Campylobacter is restricted to the gastrointestinal tract in broilers, there is still some controversy on "How, when, and to what extent Campylobacter is transferred between broiler breeder flocks and their progeny" (Cox et al., 2010).

Horizontal transmission from the environment is considered to be the most likely source of Campylobacter spp. to broilers. It is widely accepted that horizontal transmission within a flock occurs rapidly once individual birds are colonized by Campylobacter (Carrillo et al., 2004; Horrocks et al., 2009). Once established, it is very difficult to eliminate. High flock size, environmental water supplies, litter, insects, wild birds, rodents, fecal contact, personnel and other animals, may increase the risk of colonization and dissemination (Aarts et al., 1995; Line et al., 2001; Adkin et al., 2006; Horrocks et al., 2009). Feed has not been implicated in the spread of Campylobacter spp. although contaminated feed is a potentially 
important route of flock infection with Salmonella spp. (White et al., 1997). The ubiquity of Campylobacter spp. in food animals and in the environment, means that raw feed ingredients will often be contaminated with these bacteria by wild bird droppings, for example. However, Campylobacter spp. are very sensitive to dry conditions and have been shown to die quickly when present in poultry feed (Cox et al., 2010). However, it is important to remember that, as with water, feed can act as a vehicle for horizontal transmission in a broiler house once Campylobacter spp. have become established (ACMSF, 2004).

There is continuing debate about the relative contribution of vertical transmission of Campylobacter spp. from breeding flocks. Clark and Bueschkens (1985) inoculated fertile chicken eggs with C. jejuni and found that $11 \%$ of the resulting chicks at hatch had the inoculated pathogen in their intestinal tract. Lindblom et al. (1986), demonstrated that chickens raised under laboratory conditions without exposure to any farm environment continued to become colonized by $C$. jejuni. The carrier rate of $C$. jejuni in the cecal content of newly hatched chicks was found to be as high as $35 \%$ suggesting that the chicks were colonized before delivery to the farm (Chuma et al., 1994). Kazwala et al. (1990) and Van de Giessen et al. (1992) suggested that, because it is possible in a minority of flocks to isolate Campylobacter spp. from broiler chicks within 1-2 days after hatching, the bacteria could be acquired vertically. No differences between the types of Campylobacter spp. isolated in the hatcheries and the types of Campylobacter isolated in the subsequent broiler chickens were found by Pearson et al. (1996), suggesting that the Campylobacter spp. contamination may have occurred via vertical transmission (EFSA, 2006). Cox et al. (2010) recently demonstrated that $C$. jejuni can disseminate rapidly to the lymphoid organs of dayold broiler chicks following oral or intra-cloacal inoculation and persist in these sites for an extended time period. Moreover, the presence of Campylobacter in eggs and hatchery fluff may indicate the possibility of vertical transmission.

However, Callicott et al. (2006) did not find any evidence of vertical transmission of Campylobacter to the approximately 60,000 progeny parent breeders that were hatched from eggs coming from Campylobacter-positive grandparent flocks. Although this latter possibility was not excluded, it was considered as of little relevance.

\section{CONTROL STRATEGIES}

Although Campylobacter spp. have been generally regarded as sensitive to the environment exterior to animals, they are in fact more resilient than previously thought (Humphrey et al., 2007). Also, it is now recognized that campylobacters can attain the state of VBNC, that can lead to under-estimation or non-detection of the organism by culture-based techniques, yet cells in this state can still infect susceptible hosts (poultry or humans, e.g., Saha and Sanyal, 1991). However, campylobacters are sensitive to drying or even low humidities, freezing and freeze-thaw stress, oxygen, etc., so control, in general, should concentrate on these aspects where relevant. Since poultry, especially of chicken as a widely consumed and relatively cheap source of meat, is the main source of human campylobacteriosis, this is the main focus of efforts to reduce human disease.

\section{ON-FARM}

As campylobacters are common in wild and domestic animals, and therefore in the environment, it is important to minimize contamination of chicken rearing houses from such sources. Installing hygienic barriers between the external and internal environments, such as controlling the entry of farm personnel, strict hygienic routines such as washing and sanitizing of hands, changing boots and coveralls before entering, have been shown to be effective, but these barriers have often been found to be breached. Rearing chickens in a free-range system has a much greater risk of infection compared to conventional production and therefore increased difficulties in control (Humphrey et al., 2007). Minimizing the amounts of or eliminating animal protein in feed, and sanitizing the water supply, have also been effective procedures. Another factor shown to result in spread of infection, is the practice of only partly emptying a rearing house, leaving some birds to grow further. The remaining birds show an increased level of infection (Hald et al., 2001).

The use of antibiotics in food animal rearing, is no longer an acceptable approach since this has given rise to antibioticresistant strains, severely limiting the efficacy of antibiotics in treating human disease. However, the use of pre- and pro-biotics, i.e., complex polysaccharides and strains of lactic acid bacteria, has shown some promise (Hariharan et al., 2004), and could be examined further. Competitive exclusion (Nurmi principle), generally successful for control of salmonellae, has not always been successful for controlling campylobacters (Mead, 2002). Application of bacteriocin-producing bacteria (e.g., Paenibacillus polymyxa) or bacteriocins, has shown some promise and deserves further research effort (Stern et al., 2005). Similarly, application of bacteriophages lytic for $C$. jejuni to chicks, has resulted in reductions of $0.5-5 \log \mathrm{cfu} / \mathrm{g}$ of cecal contents during 5 days post-administration (Carrillo et al., 2005). Carvalho et al. (2010) achieved a reduction of $2 \mathrm{log} \mathrm{cfu} / \mathrm{g}$ in feces after administration of a three-phage lytic cocktail to chickens infected with $C$. jejuni and $C$ coli, and the effect persisted for the duration of the trials. Although there were phageresistant strains detected, in one trial (Carrillo et al., 2005) these were limited in their infectivity and were a minor component of the campylobacter flora. However, in the trials by Carvalho et al. (2010) the phage-resistant strains remained infective. Developing an effective phage treatment, by careful selection of lytic phages and use of a cocktail to minimize the appearance of phage-resistant strains, seems a viable means of reducing the level of infection in flocks and individual birds, although it is unlikely to eliminate the organisms. However, reduction in numbers of campylobacters on carcasses, can lead to a corresponding reduction in human infections.

\section{IN PROCESSING PLANTS}

Segregation of Campylobacter-positive flocks from negative flocks at the slaughter house, and slaughtering of the positive flocks, has proved to be an effective method of reducing spread of contamination (Wagenaar et al., 2006; Havelaar et al., 2007) and certified "Campylobacter-free" poultry has been produced by this method in Denmark. The segregation of flocks was achieved by using a rapid testing protocol (a 4 -h gel-based PCR technique) to identify positive from negative flocks. Strict cleaning practices after 
processing positive poultry were essential to the operation and certification (Krause et al., 2006). Along the processing line, there is a gradual reduction in the levels of campylobacters on the meat as a result of washing, de-feathering, submersion chilling, etc. If there is spread of fecal material from live birds or carcasses by rupture of the gut during evisceration, then there will be a local spread and subsequent contamination of later carcasses. Although there are no strict Critical Control Points (i.e., points at which Campylobacter can be eliminated in poultry slaughterhouses), application of Good Hygienic Practices reduces the levels of contamination considerably (Mead et al., 1995; White et al., 1997).

\section{IN DOMESTIC AND CATERING KITCHENS}

Since Campylobacter spp. are heat sensitive, in domestic and catering settings cooking temperatures and times are sufficient to eliminate the organisms, as long as this CCP is not compromised by later cross-contamination, e.g., from working surfaces and utensils not properly cleaned and sanitized. Since campylobacters can readily transfer and appear to attach to surfaces, cross-contamination

\section{REFERENCES}

Aarestrup, F. M., and Engberg, J. (2001). Antimicrobial resistance of thermophilic Campylobacter. Vet. Res. 32, 311-321.

Aarts, H. J. M., Van Lith, L. A. J. T., and Jacobs-Reitsma, W. F. (1995). Discrepancy between Penner serotyping and polymerase chain reaction fingerprinting of Campylobacter isolated from poultry and other animal sources. Lett. Appl. Microbiol. 20, 371-374.

Abeyta, C., Trost, P. A., Bark, D. H., Hunt, J. M., Kaysnet, C. A., and Wekell, M. M. (1997). The use of bacterial membrane fractions for the detection of Campylobacter species in shellfish. J. Rapid Methods Autom. Microbiol. 5, 223-247.

ACMSF. (2004). Second Report on Campylobacter. London: Advisory Committee on the Microbiological Safety of Food.

ACMSF. (2010). Foodborne Outbreaks of Campylobacter Associated with Consumption of Chicken Liver pâté/parfait. Advisory Committee on the Microbiological Safety of Food. Available at: www.food. gov.uk/multimedia/pdfs/committee /acm996pate.pdf [accessed November 2010].

Adak, G. K., Cowden, J. M., Nicholas, S., and Evans, H. S. (1995). The Public Health Laboratory Service national case-control study of primary indigenous sporadic cases of Campylobacter infection. Epidemiol. Infect. 115, 15-22.

Adkin, A., Hartnett, E., Jordan, L., Newell, D., and Davidson, H. (2006). Use of systematic review to assist the development of Campylobacter control strategies in broilers. J. Appl. Microbiol. 100, 306-315.

Alfredson, D. A., and Korolik, V. (2007). Antibiotic resistance and resistance mechanisms in Campylobacter jejuni and Campylobacter coli. FEMS Microbiol. Lett. 277, 123-132.

Allos, B. M. (2001). Campylobacter jejuni infections: update on emerging issues and trends. Clin. Infect. Dis. 32, 1201-1206.

Anonymous. (1984). Epidemiologic Notes and Reports Campylobacter Outbreak Associated with Certified Raw Milk Products - California. MMWR. October 05, 1984/33(39); 562.

Anonymous. (2005). An outbreak of Campylobacter jejuni enteritis in a school of Madrid, Spain. Euro Surveill. 10, 118-121.

Anonymous. (2007). Emerging infections program. FoodNet News Vol. 1 (1). Available at: http://cdc.gov/foodnet/news/2007/ October2007_foodnet_news.pdf

Anonymous. (2008). Campylobacter outbreak traced to raw milk in Washington. Food Poison J. Available at: http://www.foodpoisonjournal.com/ 2008/01/articles/foodborne-illnessoutbreaks/campylobacter- outbreak-traced-to-raw- milk-in-washington/ [accessed October 2010]

Anonymous. (2010). Preliminary FoodNet Data on the incidence of infection with pathogens transmitted commonly through food - 10 states, 2009. Weekly MMWR. April 16, 2010/59(14); 418-422. Available at: http://www.foodconsumer. org/newsite/Nutrition/foodborne_

needs to be avoided, and the current recommendation of transferring poultry from wrapping directly to the oven, rather than washing under running water, is a result of this need. Routinely, hot water is used to wash working surfaces and utensils in order to control the presence of Campylobacter spp. in the food processing environment. Cogan et al. (1999), however, reported that washing with hot water and with the addition of hypochlorite enhances significantly the reduction of contaminated sites. Dipping or spraying of carcasses or parts of poultry, with lactic acid, citric acid or hypochlorite, can achieve only maximal reductions of 1.0-1.5 log counts (Ellebroek et al., 2007). Freezing chicken carcasses for up to 3 weeks has been credited with reducing campylobacter risks in Norway (Sandberg et al., 2006) although the risk was not entirely eliminated. Humphrey et al. (2007) commented that there is an urgent need to inform consumers and cooks on the best ways to handle chicken in domestic and catering environments in order to minimize the spread of campylobacters and foodborne infections among the population, especially of children and immunocompromised individuals.

illnesses_on_the_decline_15041008 53.html

Asakura, M., Samosornsuk, W. Hinenoya, A., Misawa, N., Nishimura, K., Matsuhisa, A., and Yamasaki, S. (2008). Development of a cytolethal distending toxin $(c d t)$ gene-based speciesspecific multiplex PCR assay for the detection and identification of Campylobacter jejuni,Campylobacter coli and Campylobacter fetus. FEMS Immunol. Med. Microbiol. 52, 260-266.

Asakura, M., Samosornsuk, W., Taguchi, M., Kobayashi, K., Misawa, N., Kusumoto, M., Nishimura, K., Matsuhisa, A., and Yamasaki, S. (2007). Comparative analysis of cytolethal distending toxin $(c d t)$ genes among Campylobacter jejuni, C. coli and C. fetus strains. Microb. Pathog. 42, 174-183.

Atabay, H. I., and Corry, J. E. (1998). The isolation and prevalence of campylobacters from dairy cattle using a variety of methods. J. Appl. Microbiol. 84, 733-740.

Baggerman, W. I., and Koster, T. (1992). A comparison of enrichment and membrane filtration methods for the isolation of Campylobacter from fresh and frozen foods. Food Microbiol. 9, 87-94.

Bang, D. D., Scheutz, F., Ahrens, P., Pedersen, K., Blom, J., and Madsen, M. (2001). Prevalence of cytolethal distending toxin $(c d t)$ genes and CDT production in Campylobacter spp. isolated from Danish broilers. J. Med. Microbiol. 50, 1087-1094.

Baylis, C. L., MacPhee, S. A., Martin, K. W., Humphrey, T. J., and Betts, R. P. (2000). Comparison of three enrichment media for the isolation of Campylobacter spp. from foods. J. Appl. Microbiol. 89, 884-891.

Berrang, M. E., Buhr, R. J., Cason, J. A., and Dickens, J. A. (2001). Broiler carcass contamination with Campylobacter from feces during defeathering. J. Food Prot. 64, 2063-2066.

Beumer, R. R., de Vries, J., and Rombouts, F. M. (1992). Campylobacter jejuni nonculturable coccoid cells. Int. J. Food Microbiol. 15, 153-163.

Black, A. P., Kirk, M. D., and Millard, G. (2006). Campylobacter outbreak due to chicken consumption at an Australian Capital Territory restaurant. Commun. Dis. Intell. 30 , 373-377.

Blankenship, L. C., and Craven, S. E. (1982). Campylobacter jejuni survival in chicken meat as a function of temperature. Appl. Environ. Microbiol. 44, 88-92.

Blaser, M. J., Berkowitz, I. D., La Force, F. M., Cravens, J., Reller, L. B., and Wang, W. L. L. (1979). Campylobacter enteritis: clinical and epidemiological features. Ann. Int. Med. 91, 179-185.

Brown, P. E., Christensen, O. F., Clough, H. E., Diggle, P. J., Hart, C. A., Hazel, S., Kemp, R., Leatherbarrow, A. J. H., Moore, A., Sutherst, J., Turner, J., Williams, N. J., Wright, E. J., and French, N. P. (2004). Frequency and spatial distribution of environmental Campylobacter spp. Appl. Environ. Microbiol. 70, 6501-6511.

Butzler, J. P., and Oosterom, J. (1991). Campylobacter: pathogenicity and significance in foods. Int. J. Food Microbiol. 12, 1-8. 
Butzler, J. P., Dekeyser, P., Detrain, M., and Dehaen, F. (1973). Related vibrios in stools. J. Pediatrics 82,493 495.

Callicott, K. A., Fri dhriksd óttir, V., Reiersen, J., Lowman, R., Bisaillon, J., Gunnarsson, E., Berndtson, E., Hiett, K. L, Needleman, D. S., and Stern, N. J. (2006). Lack of evidence for vertical transmission of Campylobacter spp. in chickens. Appl. Environ. Microbiol. 72, 5794-5798.

Cappelier, J. M. (1997). L'état viable non cultivable chez une bactérie responsable de toxi-infections alimentaires: Campylobacter jejuni. Ph.D. thesis, Université de Nantes.

Carrillo, C. D., Taboada, E., Nash, J. H. E., Lanthier, P., Kelly, J., Lau, P. C., Verhulp, R., Mykytczuk, O., Sy, J., Findlay, W. A., Amoako, K., Gomis, S., Willson, P., Austin, J. W., Potter, A., Babiuk, L., Allan, B., and Szymanski, C. M. (2004). Genome-wide expression analyses of Campylobacter jejuni NCTC11168 reveals coordinate regulation of motility and virulence by flhA. J. Biol. Chem. 279, 20327-20338.

Carrillo, C. L., Atterbury, R. J., ElShibiny, A., Connerton, P. L. Scott, A., and Connerton, I. F. (2005). Bacteriophage therapy to reduce Campylobacter jejuni colonization of broiler chickens. Appl. Environ. Microbiol. 71, 6554-6563.

Carvalho, C. M., Gannon, B. W., Halfhide, D. E., Santos, S. B., Hayes, C. M., Roe, J. M., and Azeredo, J. (2010). The in vivo efficacy of two administration routes of a phage cocktail to reduce numbers of Campylobacter coli and Campylobacter jejuni in chickens. BMC Microbiol. 10, 232. doi: 10.1186/14712180-10-232

CAST. (1994). Foodborne Pathogens: Risk and Consequences. Task Force Report No. 122. The Council for Agricultural Science and Technology, Iowa Sate University, Ames, IA.

Ceelen, L., Decostere, A., Ducatelle, R., and Haesebrouck, F. (2006). Cytolethal distending toxin generates cell death by inducing a bottleneck in the cell cycle. Microbiol. Res. 161, 109-120.

Chantarapanont, W., Berrang, M., and Frank, J. F. (2003). Direct microscopic observation and viability determination of Campylobacter jejuni on chicken skin. J. Food Prot. 66, 2222-2230.

Charlett, A., Cowden, J. M., Frost, J. A., Gillespie, I. A., Millward, J., Neal, K. R., O’Brien, S. J., Painter, M. J., Syed,
Q., and Tompkins, D. (2003). Foreign and domestic travel and the risk of Campylobacter infection: results from a population-based sentinel surveillance scheme. J Travel Med 10,136-138.

Chuma, T., Yamada, T., Yano, K., Okamoto, K., and Yugi, H. (1994). A survey of Campylobacter jejuni in broilers from assignment to slaughter using DNA-DNA hybridization. J. Vet. Med. Sci. 56, 697-700.

Clark, A. G., and Bueschkens, D. H. (1985). Laboratory infection of chicken eggs with Campylobacter jejuni by using temperature or pressure differentials. Appl. Environ. Microbiol. 49, 1467-1471.

Cogan, T. A., Bloomfield, S. F., and Humphrey, T. J. (1999). The effectiveness of hygiene procedures for prevention of cross-contamination from chicken carcasses in the domestic kitchen. Lett. Appl. Microbiol. 29 354-358.

Corry, J. E. L., and Atabay, H. I. (1997). Comparison of the productivity of cefoperazone amphotericin teicoplan (CAT) agar and modified charcoal cefoperazone deoxycholate (mCCD) agar for various strains of Campylobacter, Arcobacter and Helicobacter pullorum. Int. J. Food Microbiol. 38, 201-219.

Corry, J. E. L., and Atabay, H. I. (2001). Poultry as a source of Campylobacter and related organisms. J. Appl. Microbiol. 90, 96S-114S.

Corry, J. E. L., Post, D. E., Colin, P., and Laisney, M. J. (1995). Culture media for the isolation of campylobacters. Int. J. Food Microbiol. 26, 43-76.

Cox, N. A., Richardson, L. J., Buhr, R. J., and Fedorka-Cray, P. J. (2010). Campylobacter can remain in various organs - WorldPoultry.net. Available at: http://www.worldpoul try.net/turkeys/management/breedi ng/campylobacter-can-remain-in-va rious-organs-7663.html [accessed October 2010].

Dastia, J. I., Tareena, A. M., Lugerta, R., Zautnera, A. E., and Groß, U. (2010). Campylobacter jejuni: a brief overview on pathogenicityassociated factors and diseasemediating mechanisms. Int. J. Med. Microbiol. 300, 205-211.

De Cesare, A., Sheldon, B. W., Smith, K. S., and Jykus, L. A. (2003). Survival and persistence of Campylobacter and Salmonella species under varying organic loads on food contact surfaces. J. Food Prot. 66, 1587-1594.

Debretsion, A., Habtemariam, T., Wilson, S., Ngawa, D., and Yehualaeshet, T. (2007). Real-time PCR assay for rapid detection and quantification of Campylobacter jejuni on chicken rinses from poultry processing plant. Mol. Cell. Probes 21, 177-181.

Debruyne, L., Gevers, D., and Vandamme, P. (2005). "Taxonomy of the family Campylobacteraceae," in Campylobacter, 3rd Edn, eds I. Nachamkin and M. J. Blaser (Washington, DC: ASM), 3-27.

D’lima, C. B., Miller, W. G., Mandrell, R. E., Wright, S. L., Siletzky, R. M., Carver, D. K., and Kathariou, S. (2007). Clonal population structure and specific genotypes of multidrugresistant Campylobacter coli from turkeys. Appl. Environ. Microbiol. 73, 2156-2164.

Docherty, L., Adams, M. R., Patel, P., and McFadden, J. (1996). The magnetic immuno-polymerase chain reaction assay for the detection of Campylobacter in milk and poultry. Lett. Appl. Microbiol. 22, 288-292.

Doyle, M. P., and Roman, D. J. (1982). Recovery of Campylobacter jejuni and Campylobacter coli from inoculated foods by selective enrichment. Appl. Environ. Microbiol. 43, 1343-1353.

Duke, L. A., Breathnach, A. S., Jenkins, D. R., Harkis, B. A., and Codd, A. W. (1996). A mixed outbreak of Cryptosporidium and Campylobacter infection associated with a private water supply. Epidemiol. Infect. 116, 303-308.

Eberhart-Phillips, J., Walker, N., Garrett, N., Bell, D., Sinclair, D., Rainger, W., and Bates, M. (1997). Campylobacteriosis in New Zealand: results of a case-control study. $J$. Epidemiol. Community Health 51, 686-691.

EFSA. (2006). The community summary report on trends and sources of zoonoses, zoonotic agents, antimicrobial resistance and foodborne outbreaks in the European union in 2005. EFSA J. 94, 1-62.

EFSA. (2007). The community summary report on trends and sources of zoonoses, zoonotic agents, antimicrobial resistance and foodborne outbreaks in the European union in 2006. EFSA J. 130, 130-155.

EFSA. (2008). Report of the task force on zoonoses data collection on the analysis of the baseline survey on the prevalence of Salmonella in slaughter pigs, in the EU, 2006-2007, part A: Salmonella prevalence estimates. EFSA J. 135, 1-111.

EFSA. (2009). The community summary report on trends and sources of zoonoses and zoonotic. Agents in the European union in 2007. EFSA J. 223, 223-440.
EFSA. (2010a). Scientific opinion on quantification of the risk posed by broiler meat to human campylobacteriosis in the EU. EFSA J. 8, 14371526.

EFSA. (2010b). Analysis of the baseline survey on the prevalence of Campylobacter in broiler batches and of Campylobacter and Salmonella on broiler carcasses in the EU, 2008. EFSA J. 8, 1503-1602.

EFSA. (2010c). The community summary report on trends and sources of zoonoses, zoonotic agents and foodborne outbreaks in the European union in 2008. EFSA J. 8, 1496-1906.

EFSA. (2011). Scientific opinion on Campylobacter in broiler meat production: controloptions and performance objectives and/or targets at different stages of the food chain. EFSA J. 9, 2105-2246.

Ellebroek, L., Lienau, J. A., Alter, T., and Schlichting, D. (2007). Effectiveness of different chemical decontamination methods on the Campylobacter load of poultry carcasses. Fleischwirtschaft 87, 224-227.

El-Shibiny, A., Connerton, P. L., and Connerton, I. F. (2005). Enumeration and diversity of campylobacters and bacteriophages isolated during the rearing cycles of free-range and organic chickens. Appl. Environ. Microbiol. 71, 1259-1266.

Endtz, H. P. (1991). Quinolone resistance in Campylobacter isolated from man and poultry following the introduction of fluoroquinolones in veterinary medicine. J. Antimicrob. Chemother. 27, 199-208.

Engberg, J., Aarestrup, F. M., Taylor, D. E., Gerner-Smidt, P., and Nachamkin, I. (2001). Quinolone and macrolide resistance in Campylobacter jejuni and C. coli: resistance mechanisms and trends in human isolates. Emerg. Infect. Dis. 7, 24-34.

Eyigor, A. Dawson, K.A., Langlois, B. E., and Pickett, C. L. (1999). Cytolethal distending toxin genes in Campylobacter jejuni and Campylobacter coli isolates: detection and analysis by PCR. J. Clin. Microbiol. 37, 1646-1650.

Federighi, M., Magras, C., Pilet, M. F., Woodward, D., Johnson, W., Jugiau, F., and Jouve, J. L. (1999). Incidence of thermotolerant Campylobacter in foods assessed by NF ISO 10272 standard: results of a two-year study. Food Microbiol. 16,195-204.

Fernández, H., Vera, F., Villanueva, M. P., and García, A. (2008). Occurrence of Campylobacter species in healthy well-nourished and malnourished children. Braz. J. Microbiol. 39, 1-3. 
Forsythe, S. J. (2000). "Food poisoning microorganisms," in The Microbiology of Safe Foods, ed. S. J. Forsythe (Abingdon: Blackwell Science Publishers), 87-148.

Foster, G., Holmes, B., Steigerwalt, A. G., Lawson, P. A., Thorne, P., Byrer, D. E., Ross, H. M., Xerry, J., Thompson, P. M., and Collins, M. D. (2004). Campylobacter insulaenigrae sp. nov., isolated from marine mammals. Int. J. Syst. Evol. Micrbiol. 54, 2369-2373.

Friedman, C. R., Neimann, J., Wegener, H. C., and Tauxe, R. V. (2000). "Epidemiology of Campylobacter jejuni infections in the United States and other industrialized nations," in Campylobacter, 2nd Edn, eds I. Nachamkin and M. J. Blaser (Washington, DC: American Society for Microbiology), 121-138.

Frost, J. A., Gillespie, I. A., and O'Brien, S. J. (2002). Public health implications of Campylobacter outbreaks in England and Wales, 1995-9: epidemiological and microbiological investigations. Epidemiol. Infect. 128, 111-118.

Gallay, A., Prouzet-Mauléon, V., Kempf, I., Lehours, P., Labadi, L., Camou, C., Denis, M., de Valk, H., Desenclos, J. C., and Mégraud, F. (2007). Campylobacter drug resistance among Humans, broiler chickens, and pigs, France. Emerging Infect. Dis. 13, 259-266.

Garénaux, A., Jugiau, F., Rama, F., Jonge, R., Denis, M., Federighi, M., and Ritz, M. (2008). Survival of Campylobacter jejuni strains from different origins under oxidative stress conditions: effect of temperature. Curr. Microbiol. 56, 293-297.

Ge, B., White, D. G., McDermott, P. F., Girard, W., Zhao, S., Susannan Hubert, S., and Meng, J. (2003). Antimicrobial-resistant Campylobacter species from retail raw meats. Appl. Environ. Microbiol. 69, 3005-3007.

Ge, Z., Schauer, D. B., and Foz, J. G. (2008). In vivo virulence properties of bacterial cytolethal-distending toxin. Cell. Microbiol. 10, 1599-1607.

Gibreel, A., and Taylor, D. E. (2006). Macrolide resistance in Campylobacter jejuni and Campylobacter coli. J. Antimicrob. Chemother. 58, 243-255.

Greig, J. R. (2003). Quinolone resistance in Campylobacter. J. Antimicrob. Chemother. 51, 740-742.

Guerry, P. (2007). Campylobacter flagella: not just for motility. Trends Microbiol. 15, 456-461.

Hald, B., Rattenborg, E., and Madsen, M. (2001). Role of batch depletion of broiler houses on the occurrence of Campylobacter spp. in chicken flocks. Lett. Appl. Microbiol. 32, 253-256.

Han, F., Lestari, S. I., Pu, S., and Ge, B. (2009). Prevalence and antimicrobial resistance among Campylobacter spp. in Louisiana retail chickens after the enrofloxacin ban. Foodborne Pathog. Dis. 6,163-171.

Hariharan, H., Murphy, G. A., and Kempf, I. (2004). Campylobacter jejuni: public health hazards and potential control methods in poultry: a review. Vet. Med. 49, 441-446.

Havelaar, A. H., Mangen, M. J., de Koeijer, A. A., Bogaardt, M., Everes, E. G., Jacobs-Reitsma, W. F., van Pelt, W., Wagenaar, J. A., de Wit, G. A., van der Zee, H., and Nauta, M. J. (2007). Effectiveness and efficiency of controlling Campylobacter on broiler chicken meat. Risk Anal. $27,831-844$.

Havelaar, A. H., Nauta, M. J., Mangen, M. J. J., de Koeijer, A. G., Bogaardt, M. J., Evers, E. G., Jacobs-Reitsma, W. F., van Pelt, W., Wagenaar, J. A., de Wit, G. A., and van der Zee, H. (2005). Costs and Benefits of Controlling Campylobacter in the Netherlands; Integrating Risk Analysis, Epidemiology and Economics. RIVM report 250911009/2005. Available at: http://www.rivm.nl/bibliotheek/ rapporten/250911009.pdf

Hazeleger, W. C., Janse, J. D., Koenraad, P. M., Beumer, R. R., Rombouts, F. M., and Abee, T. (1995). Temperature-dependent membrane fatty acid and cell physiology changes in coccoid forms of Campylobacter jejuni. Appl. Environ. Microbiol. 61, 2713-2719.

Hendrixson, D. R., and DiRita, V. J. (2004). Identification of Campylobacter jejuni genes involved in commensal colonization of the chick gastrointestinal tract. Mol. Microbiol. 52, 471-484.

Horrocks, S. M., Anderson, R. C., Nielsbet, D. J., and Ricke, S. C. (2009). Incidence and ecology of Campylobacter jejuni and coli in animals. Anaerobe 15, 18-25.

Humphrey, T., O'Brien, S., and Madsen, M. (2007). Campylobacters as zoonotic pathogens: a food production perspective. Int. J. Food Microbiol. 117, 237-257.

Igimi, S., Okada, Y., Ishiwa, A., Yamasaki, M., Morisaki, N., Kubo, Y., Asakura, H., and Yamamoto, S. (2008). Antimicrobial resistance of Campylobacter: prevalence and trends in Japan. Food Addit. Contam. Part A Chem. Anal. Control Expo. Risk Assess. 25, 1080-1083.
Inns, T., Foster, K., and Gorton, R. (2010). Cohort study of a campylobacteriosis outbreak associated with chicken liver parfait, United Kingdom. Euro Surveill. 15, 19704.

ISO. (1995). Microbiology of Food and Animal Feeding Stuffs - Horizontal Method for Detection of Thermotolerant Campylobacter. Geneva: International Organization for Standardization. [ISO 10272: 1995. E].

ISO. (2006a). Microbiology of Food and Animal Feeding Stuffs - Horizontal Method for Detection and Enumeration of Campylobacter spp. Part 1: Detection Method. Geneva: International Organization for Standardization. [ISO 10272-1:2006].

ISO. (2006b). Microbiology of Food and Animal Feeding Stuffs - Horizontal Method for Detection and Enumeration of Campylobacter spp. Part 2: Colony Count Technique. Geneva: International Organization for Standardization. [ISO/TS 102722:2006].

Jagannathan, A., and Penn, C. (2005) "Motility," in Campylobacter. Molecular and Cellular Biology, eds J. M. Ketley and M. E. Konkel (Norfolk: Horizon Bioscience), 331-347.

Jain, D., Prasad, K. N., Sinha, S., and Husain, N. (2008). Differences in virulence attributes between cytolethal distending toxin positive and negative Campylobacter jejuni strains. J. Med. Microbiol. 57, 267-272.

Jakopanec, I., Borgen, K., Vold, L., Lund, H., Forseth, T., Hannula, R., and Nygård, K. (2008). A large waterborne outbreak of campylobacteriosis in Norway: the need to focus on distribution system safety. $B M C$ Infect. Dis. 8, 128. doi: 10.1186/14712334-8-128

Jones, D. M., Sutcliffe, E. M., and Curry, A. (1991). Recovery of viable but nonculturable Campylobacter jejuni. J. Gen. Microbiol. 137, 2477-2482.

Kapperud, G., Skjerve, E., Bean, N. H., Ostroff, S. M., and Lassen, J. (1992). Risk factors for sporadic Campylobacter infections: results for a case control study in southeastern Norway. J. Clin. Microbiol. 30, 3117-3121.

Karagiannis, I., Sideroglou, T. Gkolfinopoulou, K., Tsouri, A., Lampousaki, D., Velonakis, E. N., Scoulica, E. V., Mellou, K., Panagiotopoulos, T., and Bonovas, S. (2010). A waterborne Campylobacter jejuni outbreak on a Greek island. Epidemiol. Infect. 138, 1726-1734.

Kazwala, R. R., Collins, J. D., Hannan, R. A., and Crinion, H. O. M. (1990).
Factors responsible for the introduction and the spread of Campylobacter jejuni in commercial poultry production. Vet. Rec. 121, 305-306.

Kim, J. S., Kim, J. W., and Kathariou, S. (2008). Differential effect of temperature on natural transformation to erythromycin and nalidixic acid resistance in Campylobacter coli. Appl. Environ. Microbiol. 74, 6121-6125.

King, S., and Adams, M. C. (2008). Incidence of Campylobacter in processed poultry: is it a concern for human health? J. Food Saf. 28, 376-388.

Koenraad, P. M., Jacobs-Reitsma, W. F., van der Laan, T., Beumer, R. R., and Rombouts, F. M. (1995). Antibiotic susceptibility of Campylobacter isolates from sewage and poultry abattoir drain water. Epidemiol. Infect. 115, 475-483.

Kramer, J. M., Frost, J. A., Bolton, F. J., and Wareing, D. R. (2000). Campylobacter contamination of raw meat and poultry at retail sale: identification of multiple types and comparison with isolates from human infection. J. Food Prot. 63, 1654-1659.

Krause, M., Josefsen, M. H., Lund, M., Jacobsen, N. R., Brorsen, L., Moos, M., Stockmarr, A., and Hoorfar, J. (2006). Comparative, collaborative, and on-site validation of a TaqMan PCR method as a tool for certified production of fresh, CampylobacterFree Chickens. Appl. Environ. Microbiol. 72, 5463-5468.

Lara-Tejero, M., and Galan, J. E. (2001). CdtA, CdtB and CdtC form a tripartite complex that is required for cytolethal distending toxin activity. Infect. Immun. 69, 4358-4365.

Lee, A., Smith, S. C., and Coloe, P. J. (1998). Survival and growth of Campylobacter jejuni after artificial inoculation onto chicken skin as a function of temperature and packaging conditions. J. Food Prot. 61, 1609-1614.

Lehtola, M. J., Pitkanen, T., Miebach, L., and Miettinen, I. T. (2006). Survival of Campylobacter jejuni in potable water biofilms: a comparative study with different detection methods. Water Sci. Technol. 54, 57-61.

Levin, R. E. (2007). Campylobacter jejuni: a review of its characteristics, pathogenicity, ecology, distribution, subspecies characterization and molecular methods of detection. Food Biotechnol. 21, 271-347.

Lindblom, G. B., Sjogren, E., and Kaijser, B. (1986). Natural Campylobacter colonization in chickens raised under different environmental conditions. J. Hyg. 96, 385-391. 
Line, J. E., Stern, N. J., Lattuada, C. P., and Benson, S. T. (2001). Comparison of methods for recovery and enumeration of Campylobacter from freshly processed broilers. J. Food Prot. 64, 982-986.

Luangtongkum, T., Morishita, T. Y., Ison, A. J., Huang, S., McDermott, P. F., and Zhang, Q. (2006). Effect of conventional and organic production practices on the prevalence and antimicrobial resistance of Campylobacter spp. in poultry. Appl. Environ. Microbiol. 72, 3600-3607.

Lucey, B., Cryan, B., O'Halloran, F., Wall, P. G., Buckley, T. G., and Fanning, S. (2002). Trends in antimicrobial susceptibility among isolates of Campylobacter species in Ireland and the emergence of resistance to ciprofloxacin. Vet. Rec. 151, 317-320.

Mason, M. J., Humphrey, T. J., and Martin, K. W. (1999). Isolation of sublethally injured campylobacters from poultry and water sources. $\mathrm{Br}$. J. Biomed. Sci. 56, 2-5.

Mazi, W., Senok, A., Al-Mahmeed, A., Arzese, A., Bindayna, K., and Botta, G. (2008). Trends in antibiotic sensitivity pattern and molecular detection of tet $(\mathrm{O})$ mediated tetracycline resistance in Campylobacter jejuni isolates from human and poultry sources. Jpn. J. Infect. Dis. 61, 82-84.

Mazick, A., Ethelberg, S., MøllerNielsen, E., Mølbak, K., and Lisby, M. (2006). An outbreak of Campylobacter jejuni associated with consumption of chicken, Copenhagen, 2005. Euro Surveill. 11, 622.

McDermott, P. F., Bodeis-Jones, S. M., Fritsche, T. R., Jones, R. N., Walker, R. D., and The Campylobacter Susceptibility Testing Group. (2005). Broth microdilution susceptibility testing of Campylobacter jejuni and the determination of quality control ranges for fourteen antimicrobial agents. J. Clin. Microbiol. 43, 6136-6138.

McKay, A. M. (1992). Viable but nonculturable forms of potentially pathogenic bacteria in water. Lett. Appl. Microbiol. 12, 129-135.

McMeekin, T. A., Thomas, C. J., and Pennington, P. I. (1984). Contamination and decontamination of poultry carcass neck tissue. J. Food Safety 6, 79-88.

Mead, G. C. (2002). Factors affecting intestinal colonization of poultry by Campylobacter and role of microflora in control. Worlds Poult. Sci. J. 58, 169-178.

Mead, G. C., Hudson, W. R., and Hinton, M. H. (1995). Effects of changes in processing to improve hygiene control on contamination of poultry carcasses with Campylobacter. Epidemiol. Infect. 115, 495-500.

Moore, J., Barton, M., Blair, I., Corcoran, D., Dooley, J., Fanning, S., Kempf, I., Lastovica, A., Lowery, C., and Seal, B. (2006). The epidemiology of antibiotic resistance in Campylobacter spp. Microbes Infect. 8, 1955-1966.

Moore, J. E., Corcoran, D., Dooley, J. S. G., Fanning, S., Lucey, B., Matsuda, M., McDowell, D. A., Mégraud, F., Millar, B. C., O'Mahony, R., O’Riordan, L., O’Rourke, M., Rao, J. R., Rooney, J., Sails, A., and Whyte, P. (2005). Campylobacter - Article review. Vet. Res. 36, 351-382.

Moore, J. E., and Madden, R. H. (2001). Survival of Campylobacter coli in porcine liver. Food Microbiol. 18, 1-10.

Nadeau, E., Messier, S., and Quessy, S. (2002). Prevalence and comparison of genetic profiles of Campylobacter strains isolated from poultry and sporadic cases of campylobacteriosis in humans. J. Food Prot. 65, 73-78.

Nelson, J. M., Chiller, T. M., Powers, J. H., and Angulo, F. J. (2007). Fluoroquinolone resistant Campylobacter species and the withdrawal of fluoroquinolones from use in poultry: a public health success story. Clin. Infect. Dis. 44, 977-980.

Nesbakken, T., Eckner, K., Hoidal, H. K., and Rotterud, O. (2003). Occurrence of Yersinia enterocolitica and Campylobacter spp. in slaughter pigs and consequences for meat inspection, slaughtering and dressing procedures. Int. J. Food Microbiol. 80, 231-240.

Newell, D. G., and Wagenaar, J. A. (2000). "Poultry infections and their control at the farm level," in Campylobacter, 2nd Edn, eds I. Nachamkin and M. J. Blaser (Washington, DC: American Society of Microbiology Press), 497-510.

Nguyen, H. T. T., Corry, J. E. L., and Miles, C. A. (2006). Heat resistance and mechanism of heat inactivation in thermophilic campylobacters. Appl. Environ. Microbiol. 72, 908-913.

Norström, M., Johnsen, G., Hofshagen, M., Tharaldsen, H., and Kruse, H. (2007). Antimicrobial resistance in Campylobacter jejuni from broilers and broiler house environments in Norway. J. Food Prot. 70, 736-737.

Nygard, K., Andersson, Y., Rottingen, J. A., Svensson, A., Lindback, J., Kistemann, T., and Giesecke, J. (2004). Association between environmental risk factors and Campylobacter infections in Sweden. Epidemiol. Infect. 132, 317-325.

On, S. L. W. (2001). Taxonomy of Campylobacter, Arcobacter, Helicobacter and related bacteria: current status, future prospects and immediate concerns. J. Appl. Microbiol. 90, 1S-15S.

Orr, K. E., Lighfoot, N. F., Sisson, P. R. Harkis, B. A., Tveddle, J. L., Boyd, P., Carroll, A., Jackson, C. J., Wareing, D. R. A., and Freeman, R. (1995) Direct milk excretion of Campylobacter jejuni in a dairy cow causing cases of human enteritis. Epidemiol. Infect. 114, 15-24.

Park, S. F. (2002). The physiology of Campylobacter species and its relevance to their role as foodborne pathogens. Int. J. Food Microbiol. 74, 177-188.

Pearson, A. D., Greenwood, M. H., Feltham, R. K., Healing, T. D., Donaldson, J., Jones, D. M., and Colwell, R. R. (1996). Microbial ecology of Campylobacter jejuni in a United Kingdom chicken supply chain: Intermittent common source, vertical transmission, and amplification by flock propagation. Appl. Environ. Microbiol. 62, 4614-4620.

Pickett, C. L., Pesci, E. C., Cottle, D. L., Russell, G., Erdem, A. N., and Zeytin, H. (1996). Prevalence of cytolethal distending toxin production in Campylobacter jejun and relatedness of Campylobacter sp. $c d t B$ genes. Infect. Immun. 64 2070-2078.

Poly, F., and Guerry, P. (2008). Pathogenesis of Campylobacter. Curr. Opin. Gastroenterol. 24, 27-31.

Porter, I. A., and Reid, T. M. S. (1980). A milk-borne outbreak of Campylobacter infection. J. Hyg. (Lond.) 84, 415-419.

Portner, D. C., Leuschner, R. G. K. and Murray, B. S. (2007). Optimising the viability during storage of freeze-dried cell preparations of Campylobacter jejuni. Cryobiology 54, 265-270.

Potter, M. E., Blaser, M. J., Sikes, R. K., Kaufmann, A. F., and Wells, J. G. (1983). Human Campylobacter infection associated with certified raw milk. Am. J. Epidemiol. 117, 475-483.

Price, L. B., Lackey, L. G., Vailes, R. and Silbergeld, E. (2007). The persistence of fluoroquinolone-resistant Campylobacter in poultry production. Environ. Health Perspect. 115, 1035-1039.

Rautelin, H., Renkonen, O. V., and Kosunen, T. U. (1991). Emergence of fluoroquinolone resistance in Campylobacter jejuni and
Campylobacter coli in subjects from Finland. Antimicrob. Agents Chemother. 35, 2065-2069.

Robinson, D. A., Edgar, W. M., Gibson, G. L., Matchett, A. A., and Robertson, L. (1979). Campylobacter enteritis associated with consumption of unpasteurised milk. Br. Med. J. 1, 1171-1173

Rozynek, E., Dzierzanowska-Fangrat, K., SzczezepaÅ, B., Wardak, S. Szych, J., Konieczny, P., Albrecht, P., and Dzierzanowska, D. (2007). Trends in antimicrobial susceptibility of Campylobacter isolates in Poland (2000-2007). Pol. J. Microbiol. 58,111-115.

Saeed, A. M., Harris, N. V., and DiGiacomo, R. F. (1993). The role of exposure to animals in the etiology of Campylobacter jejuni/coli enteritis. Am. J. Epidemiol. 137, 108-114.

Saha, S. K., and Sanyal, S. C. (1991). Recovery of injured Campylobacter jejuni after animal passage. Appl. Environ. Microbiol. 57, 3388-3389.

Said, B., Wright, F., Nichols, G. L., Reacher, M., and Rutter, M. (2003). Outbreaks of infectious disease associated with private drinking water supplies in England and Wales 1970-2000. Epidemiol. Infect. 130, 469-479.

Samosornsuk, W., Asakura, M., Yoshida, E., Taguchi, M., Kazuhiko, N., Boonchuay, E., Vongsavanh, P., Wanpen, C., and Shinji, Y. (2007). Evaluation of a cytolethal distending toxin $(c d t)$ gene-based speciesspecific multiplex PCR assay for the identification of Campylobacter strains isolated from poultry in Thailand. Microbiol. Immunol. 51, 909-917.

Sánchez, R., Fernandez-Baca, V., Diaz, M. D., Munoz, P., RodriguezCréixems, M., and Bouza, E. (1994). Evolution of susceptibilities of Campylobacter spp. to quinolones and macrolides. Antimicrob. Agents Chemother. 38, 1879-1882.

Sandberg, M., Nygård, K., Meldal, H., Valle, P. S., Kruse, H., and Skjerve, E. (2006). Incidence trend and risk factors for Campylobacter infections in humans in Norway. BMC Public Health 6, 179. doi: 10.1186/14712458-6-179

Scherer, K., Bartelta, E., Sommerfelda, C., and Hildebrandt, G. (2006). Comparison of different sampling techniques and enumeration methods for the isolation and quantification of Campylobacter spp. in raw retail chicken legs. Int. J. Food Microbiol. 108, 115-119. 
Schorr, D., Schmid, H., Rieder, H. L., Baumgartner, A., Vorkauf, H., and Burnens, A. (1994). Risk factors for Campylobacter enteritis in Switzerland. Zentralbl. Hyg. Umweltmed. 196, 327-337.

Simmons, N. A., and Gibbs, F. J. (1979). Campylobacter spp. in oven-ready poultry. J. Infect. 1 , 159-162.

Skirrow, M. B. (1977). Campylobacter enteritis: a "new" disease. Br. Med. J. 2,9 .

Skirrow, M. B. (1998). "Campylobacteriosis," in Zoonoses, eds S. R. Palmer, S. R. Lord Soulsby, and D. I. H. Simpson (New York: Oxford University Press), 37-46.

Skirrow, M. B. (2006). John McFadyean and the centenary of the first isolation of Campylobacter species. Clin. Infect. Dis. 43, 1213-1217.

Smith, J. L., and Fratamico, P. M. (2010). Fluoroquinolone resistance in Campylobacter. J. Food Prot. 73, 1141-1152.

Smole Možina, S., Kurincic, C. M., Kramar, A., Uršicc, S., and Katalinic, V. (2009). Prevalence and resistance against different antimicrobial compounds of Campylobacter spp. in/from retail poultry. Meat Technol. $50,112-120$

Stern, N. J., Jones, D. M., Wesley, I. V., and Rollins, D. M. (1994). Colonization of chicks by nonculturable Campylobacter spp. Lett. Appl. Microbiol. 18, 333-336.

Stern, N. J., and Kazmi, S. U. (1989). "Campylobacter jejuni," in Foodborne Bacterial Pathogens, ed. M. P. Doyle (New York: Marcel Dekker Inc.), 71-110.

Stern, N. J., and Kotula, A. W. (1982). Survival of Campylobacter jejuni inoculated into ground beef. Appl. Environ. Microbiol. 44, 1150-1153.

Stern, N. J., Svetoch, E. A., Eruslanov, B. V., Kovalev, Y. N., Volodina, L. I., Perelygin, V. V., Mitsevich, E. V., Mitsevich, I. P., and Levchuk, V. P. (2005). Paenibacillus polymyxa purified bacteriocin to control Campylobacter jejuni in chickens. J. Food Prot. 68, 1450-1453.
Stuart, T. L., Sandhu, J., Stirling, R., Corder, J., Ellis, A., Misa, P., Goh, S., Wong, B., Martiquet, P., Hoang, L., and Galanis, E. (2010). Campylobacteriosis outbreak associated with ingestion of mud during a mountain bike race. Epidemiol. Infect. 138, 1695-1703.

Studahl, A., and Andersson, Y. (2000). Risk factors for indigenous Campylobacter infection: a Swedish casecontrol study. Epidemiol. Infect. 125, 269-275.

Takkinen, J., Ammon, A., Robstad, O., Breuer, T., and Campylobacter Working Group. (2003). European survey on Campylobacter surveillance and diagnosis 2001. Euro Surveill. 8, 207-213.

Tauxe, R., Kruse, H., Hedberg, C., Potter, M., Madden, J., and Wachsmuth, K. (1997). Microbial hazards and emerging issues associated with produce: a preliminary report to the National Advisory Committee on Microbiologic Criteria for Foods. J. Food Prot. 60, 1400-1408.

Tauxe, R. V. (1992). "Epidemiology of Campylobacter jejuni infection in the United States and other industrialized nations," Chapter 2, in: Campylobacter jejuni: Current Status and Future Trends, eds I. Nachamkin, M. J. Blaser, and L. S. Tompkins (Washington, DC: American Association of Microbiologists), 9-19.

Tran, T. T. (1998). A blood-free enrichment medium for growing Campylobacter spp. under aerobic conditions. Lett. Appl. Microbiol. 26, 145-148.

Van de Giessen, A., Mazurier, S. I., Jacobs-Reitsma, W., Jansen, W., Berkers, P., Ritmeester, W., and Wernars, K. (1992). Study on the epidemiology and control of Campylobacter jejuni in poultry broiler flocks. Appl. Environ. Microbiol. 58, 1913-1917.

Van Deun, K., Haesebrouck, F., Hendrickx, M., Favoreel, H., Dewulf, J., Ceelen, L., Dumez, L., Messens, W., Leleu, S., Van Immersal, F., Ducatelle,
R., and Pasmans, F. (2007). Virulence properties of Campylobacter jejuni isolates of poultry and human origin. J. Med. Microbiol. 56, 1284-1289.

van Vliet, A. H., and Ketley, J. M. (2001) Pathogenesis of enteric Campylobacter infection. Symp. Ser. Soc. Appl. Microbiol. 30, 45S-56S.

Vandamme, P. (2000). "Taxonomy of the family Campylobacteraceae," in Campylobacter, eds I. Namchamkin and M. J. Blaser (Washington, DC: ASM), 3-27.

Vandamme, P., Debruyne, L., De Brandt, E., and Falsen, E. (2010). Reclassification of Bacteroides ureolyticus as Campylobacter ureolyticus comb. nov., and emended description of the genus Campylobacter. Int. J. Syst. Evol. Microbiol. 60, 2016-2022.

Wagenaar, J. A., Mevius, D. J., and Havelaar, A. H. (2006). Campylobacter in primary animal production and control strategies to reduce the burden of human campylobacteriosis. Rev. Off. Int. Epizoot. 25, 581-594.

Waller, D. F., and Ogata, S. A. (2000) Quantitative immunocapture PCR assay for detection of Campylobacter jejuni in foods. Appl. Environ. Microbiol. 66, 4115-4118.

White, P. L., Baker, A. R., and James, W. O. (1997). Strategies to control Salmonella and Campylobacter in raw poultry products. Rev. Sci. Tech. 16, 525-541.

WHO. (2005). WHO global Salm-Surv Strategic Plan 2006-2010. Available at: http://www.who.int/gfn/general/ documents/GSS_STRATEGICPLAN 2006_10.pdf

Wills, W. L., and Murray, C. (1997). Campylobacter jejuni seasonal recovery observations of retail market broilers. Poult. Sci. 76, 314-317.

Wilma, C., Hazeleger, R. R., Beumer, F. D., and Rombouts, F. M. (1992). The use of latex agglutination tests for determining Campylobacter species. Lett. Appl. Microbiol. 14, 181-184.

Wilson, I. G., and Moore, J. E. (1996). Presence of Salmonella spp. and
Campylobacter spp. in shellfish. Epidemol. Infect. 116, 147-153.

Yamasaki, S., Asakura, M., Tsukamoto, T., Faruque, S. M., Deb, R., and Ramamurthy, T. (2006). Cytolethal distending toxin (CDT): genetic diversity, structure and role in diarrheal disease. Toxin Rev. 25, 61-88.

Zanetti, F., Varoli, O., Stampi, S., and DeLuca, G. (1996). Prevalence of thermophilic Campylobacter and Arcobacter butzleri in food of animal origin. Int. J. Food Microbiol. 33, 315-321.

Zilbauer, M., Dorrell, N., Wren, B. W., and Bajaj-Elliott, M. (2008). Campylobacter jejuni mediated disease pathogenesis: an update. Trans. R. Soc. Trop. Med. Hyg. 120, 123-129.

Zweifel, M. A. Z., and Stephan, R. (2004). Prevalence and characteristics of Shiga toxin-producing Escherichia coli, Salmonella spp. and Campylobacter spp. isolated from slaughtered sheep in Switzerland. Int. J. Food Microbiol. 92, 45-53.

Conflict of Interest Statement: The authors declare that the research was conducted in the absence of any commercial or financial relationships that could be construed as a potential conflict of interest.

Received: 08 June 2011; accepted: 07 September 2011; published online: 27 September 2011.

Citation: Silva J, Leite D, Fernandes M, Mena C, Gibbs PA and Teixeira P (2011) Campylobacter spp. as a foodborne pathogen: a review. Front. Microbio. 2:200. doi: 10.3389/fmicb.2011.00200

This article was submitted to Frontiers in Food Microbiology, a specialty of Frontiers in Microbiology.

Copyright (c) 2011 Silva, Leite, Fernandes, Mena, Gibbs and Teixeira. This is an open-access article subject to a nonexclusive license between the authors and Frontiers Media SA, which permits use, distribution and reproduction in other forums, provided the original authors and source are credited and other Frontiers conditions are complied with. 